\title{
Kestävyysajattelu ILO:n vihreän työn raporteissa ja työelämän tutkimus kestävyyssiirtymässä
}

\section{Tiivistelmä}

Tarkastelemme artikkelissamme, miten työelämän ja ympäristökysymysten yhtymäpintoja on kuvattu Kansainvälisen työjärjestö ILO:n vihreän työn raporteissa. Esitämme, että raporteissa on käyttökelpoisia jäsennyksiä siitä, miten työelämän teemat ja ympäristökysymykset nivoutuvat yhteen. Listaamme ILO:n julkisesti verkossa saatavilla olevat vihreän työn raportit ja kuvaamme, millaisista teemoista raporteissa on kirjoitettu. Keskitymme tarkemmin kahteen keskeiseen raporteissa esille nousevaan teemaan: (1) ilmastonmuutoksen ja (2) kestävyyssiirtymän vaikutuksiin työhön ja työllisyyteen. Tarkastelemme vihreän työn raportteja tukeutuen aikaisemmassa tutkimuksessa tunnistettuun eroon heikon ja vahvan kestävyysajattelun välillä. Lisäksi esitämme, että raporttien teemoihin perehtyminen antaa työelämän tutkijoille ja kehittäjille välineitä oikeudenmukaisen siirtymän ymmärtämiseksi ja edistämiseksi. Johtopäätöksenä esitämme, että työelämän tutkimusta ja kehittämistä tulisi yhä enemmän tarkastella paitsi ylikansallisen myös ylisukupolvisen reiluuden sekä lajien välisen oikeudenmukaisuuden näkökulmista. 


\section{Johdanto}

Keskustelu ympäristökysymyksistä on lisääntynyt huomattavasti viimeisen vuosikymmenen aikana. Ihmisen aiheuttama ilmastonmuutos ja lajikato ovat nousseet jokapäiväiseen uutisvirtaan, poliitikkojen puheisiin sekä poliittisiin ohjelmiin. Esimerkiksi vuonna 2019 laadittu Rinteen hallitusohjelma linjaa, että Suomi pyrkii maailman ensimmäiseksi fossiilivapaaksi hyvinvointiyhteiskunnaksi. Edessä olevasta muutoksesta puhutaan kestävyyssiirtymänä tai kestävyysmurroksena. Suomalaisen työelämän tutkimuksessa työn ja ympäristökysymysten tutkiminen on ollut vähäistä ja hajanaista, vaikka yhä vakavammat ekososiaaliset kriisit vaikuttavat siihen, millaista on reilu, toimeentuloon riittävä ja palkitseva työ. Tässä artikkelissa esitämme, että ympäristökysymysten tulisi pikaisesti yleistyä työelämän tutkijoiden agendalla, mikäli ala haluaa jatkossa pyrkiä ymmärtämään ja palvelemaan työelämän toimijoiden tarpeita.

Suomalaisessa työelämän tutkimuksessa kestävän kehityksen teemoja ja ympäristönäkökulmia on nostanut esille muutama asiaan paneutunut tutkija. Aikaisempia tutkimuksia yhdistää ajatus siitä, että työelämä on keskeisessä roolissa haettaessa ratkaisuja kestävyyskriisiin. Esimerkiksi Antti Kasvio ja Timo Räikkönen (Kasvio \& Räikkönen 2010; Kasvio ym. 2013) ovat tutkimushankkeissaan ja -työssään hahmotelleet puitteita ekologisesti kestävälle työelämälle (Räikkönen 2013; 2016) sekä kestävän työn ulottuvuuksille (Kasvio 2009; 2012; 2014). Lisäksi kestävää työtä on lähestytty sosiaali- ja työpolitiikan näkökulmista kiinnittäen huomiota työn, toimeentulon ja hyvinvoinnin kysymyksiin kestävyyskriisissä ja kestävyyssiirtymässä (Hirvilammi ym. 2016; Hirvilammi \& Joutsenvirta 2020). Työelämän kestävyyttä on tarkasteltu myös kestävien työjärjestelmien (sustainable work systems) näkökulmasta (Alasoini 2003; Docherty ym. 2008; Kira \& van Eijnatten 2010). Kestävien työjärjestelmien tutkimuksessa on usein painottunut sosiaalisen ja inhimillisen kestävyyden edistäminen ympäristönäkökulmien sijaan. Sen sijaan työn roolista ja määritelmästä fossiilitalousjärjestelmän ylläpidossa ja ekososiaalisessa kestävyyssiirtymässä ovat olleet kiinnostuneita erityisesti suomalaiset degrowth - ja kestävyystutkijat (Järvensivu ym. 2012; Järvensivu 2016; Houtbeckers \& Taipale 2017; Lahikainen \& Toivanen 2019).

Artikkelimme lähtökohtana on täydentää jo aikaisemmassa suomalaisessa tutkimuksessa (Hirvilammi ym. 2016; Räikkönen 2016) esitettyä väitettä, että työelämä 
on keskeisessä roolissa haettaessa ratkaisuja globaaleihin ympäristöongelmiin. Teemanumeron hengessä kohdistamme katseen Yhdistyneiden kansakuntien alaiseen Kansainväliseen työjärjestö ILO:on (International Labour Organization), joka järjestönä tunnetaan työelämän oikeuksien ja perusperiaatteiden edistäjänä. Siksi vähemmälle huomiolle on saattanut jäädä se, että työn ja toimeentulon keskeinen rooli kestävän kehityksen tavoitteiden saavuttamisessa on tunnistettu ILO:ssa jo 1970-luvulla (Olsen \& Kemter 2012). ILO on pitänyt oikeudenmukaisen ja ihmisarvoisen työn näkökulmaa esillä kansainvälisissä ympäristösopimusneuvotteluissa eri vuosikymmenillä. Vuodesta 2007 alkaen se on myös tutkinut ja edistänyt ekologisesti ja sosiaalisesti kestävämpää työelämää vihreän työn aloitteellaan (Green Jobs Initiative) ja ohjelmallaan (Green Jobs Programme). Vihreän työn raporteilla ja toimenpideohjelmilla on ollut tässä työssä keskeinen rooli (ILO 2013).

ILO:a ja muita kansainvälisiä organisaatioita on kritisoitu sitä, että niiden tapa puhua vihreästä työstä osaltaan pitää yllä kestämätöntä luonnonympäristön sekä heikommassa asemassa olevien ihmisten ja työntekijöiden kohtelua (Barca 2015). Aikaisemmassa tutkimuksessa on eritelty vihreän työn ja kestävän kehityksen ohjelmien ideologioita ja puhetapoja (ks. esim. Davidson 2014; Felli 2014). Niistä käy ilmi, että kansainväliset toimijat sisäistävät erilaisia ristiriitaisiakin puhetapoja laatiessaan kestävää kehitystä edistäviä ohjelmia.

Tarkastelemme artikkelissamme erityisesti sitä, miten ILO:n viimeisen viidentoista vuoden aikana julkaisemat raportit kuvaavat edessä olevia muutoksia. Artikkeli vastaa kysymyksiin: Millaisia vihreän työn teemoja ILO:n raporteissa esiintyy? Minkälaista kestävyysajattelua nämä heijastelevat? Miten ILO:n raporttien teemat näkyvät suomalaisessa työelämän tutkimuksessa ja kehittämisessä?

Aikaisemmin ILO:n raportteja ovat Suomessa sivunneet muun muassa Antero Honkasalo (2012) ja Ilmo Massa (2009) tarkastellessaan vihreästä taloudesta, vihreästä sopimuksesta (Green New Deal) ja vihreästä työstä käytyä keskustelua. Suomeksi on puhuttu hieman vaihtelevasti vihreästä työstä, vihreistä töistä ja vihreistä työpaikoista viitattaessa vihreän työn aloitteisiin ja ohjelmiin. Tässä tekstissä käytämme vihreän työn käsitettä kuvaamaan ILO:n ohjelmia ja aloitteita teemasta.

Käymme läpi ILO:n vuosien 2008-2019 välillä julkaisemien vihreän ja kestävän työn ohjelmapapereiden, raporttien ja tutkimuspapereiden (yhteensä 11 kappaletta) sisältöjä. Ennen raporttien teemojen esittelyä kuvaamme lyhyesti aikaisemmassa ympäristöpoliittisten ohjelmien tutkimuksessa havaittua eroa vahvan ja heikon 
kestävyysajattelun välillä. Sen jälkeen kartoitamme ILO:n julkaisemien vihreän työn raporttien taustaa ja tarkoitusta. Esittelemme saatavilla olevat vihreän työn raportit sekä raporttien teemat. Lopuksi jäsennämme teemoja aikaisemman kirjallisuuden valossa ja suhteutamme niitä suomalaiseen vihreän työn tutkimukseen.

\section{Kestävyysajattelu vihreän työn ohjelmissa}

Vaikka kestävän kehityksen ja vihreän työn edistämiseen tähtäävien poliittisten ohjelmien kriittisessä tarkastelussa on hyödynnetty erilaisia teoreettisia jaotteluita ja lähtökohtia, on analyyseissa samankaltaisuuksia. Usein tarkastelun kohteeksi otetaan poliittisten ohjelmien taustalla vaikuttavat poliittiset ideologiat (Davidson 2014) tai diskurssit (Hajer 1995). Niiden avulla on pyritty selvittämään, miten erilaiset tavat ymmärtää ympäristöongelmat määrittävät tarjottuja ratkaisumalleja. Tarkastelun lähtökohtana on havainto siitä, että vaikka eri toimijoilla on yhteinen ymmärrys tarpeesta siirtyä kohti ekologisesti kestävämpää yhteiskuntarakennetta, talousjärjestelmää tai työelämää, eroavat näkemykset siitä, miten kestävyys voidaan tai tulisi saavuttaa.

Timo Räikkönen (2011) on tarkastellut työn ja työelämän vihertämistä nojautuen jaotteluun ihmiskeskeinen reformistisen "environmentalismin" ja luontokeskeisen tai ekosentrisen (radikaali)ekologian välillä. Nämä lähestymistavat poikkeavat toisistaan esimerkiksi siinä, nähdäänkö luonto sille annetun välinearvon kautta vai arvokkaana itsessään. Kun ympäristöongelmia tarkastellaan reformistisista lähtökodista, ratkaisuna nähdään teknologinen kehitys ja resurssi- tai ekotehokkuuden kehittäminen nykyisen talouskasvuun pohjautuvan talousjärjestelmän puitteissa. Ajattelua on kutsuttu myös ekologiseksi modernisaatioksi (Hajer 1995; Ewing 2017; Johansson \& Henriksson 2020). Luontokeskeisyyteen pohjautuvat lähestymistavat, kuten ekohumanismi, syväekologia, ekologinen taloustiede tai degrowth-ajattelu, puolestaan korostavat paitsi tarvetta kyseenalaistaa ja laajentaa nykyistä ajattelutapaa myös tarvetta uudistaa politiikan ja talouden instituutiot edistämään kestävyyttä (Ewing 2017).

Työelämää tarkasteltaessa ensin mainittua reformistista ajattelua edustavat ohjelmat, joilla korostetaan ympäristöpoliittisten uudistusten yhteyttä vihreisiin työpaikkoihin ja vihreään kasvuun. Radikaalimpi ajattelu puolestaan kyseenalaistaa 
kasvuajattelun ja peräänkuuluttaa kokonaisvaltaisempaa irtaantumista talouskasvusta. Tällöin kyseenalaistetaan palkkatyön nykyinen asema ja rooli. Lisäksi peräänkuulutetaan kokonaisvaltaisempaa näkemystä työstä, johon kuuluu myös esimerkiksi palkaton hoiva- ja vapaaehtoistyö, sekä ehdotetaan usein perustuloa. Räikkösen kysymyksenasettelu vihreyden eri sävyistä vihreää työtä tarkasteltaessa heijasteleekin yleisempää kysymyksenasettelua heikon ja vahvan kestävyysnäkökulman välillä (ks. esim. Johansson \& Henriksson 2020), vaikka vahvaa kahtiajakoa on myös kyseenalaistettu (Geels ym. 2015).

Aikaisempi tutkimus korostaa, että kansainvälisten toimijoiden, kuten ILO:n, kestävän kehityksen ohjelmat heijastelevat laajempaa poliittista ilmapiiriä (Felli 2014). Viimeisten vuosikymmenten aikana ympäristöpoliittisessa ohjauksessa ovat korostuneet ekologisen modernisaation keinovalikoimaan kuuluvat kestävyyteen ohjaavat tavat, jotka sopivat yhteen voimistuneen uusliberalistisen poliittisen ilmapiirin kanssa. Tällaisia painopisteitä ovat olleet kuluttajien ohjaaminen vihreisiin valintoihin, investoinnit cleantechiin sekä eko- ja resurssitehokkuuteen ja usko yritysten omaehtoiseen haluun toimia vastuullisesti yritysvastuuajattelun hengessä (Johansson \& Henriksson 2020). Haluttomuus rajoittaa tai ohjata taloudellista toimintaa kestävyyden edistämiseksi heijastuu myös kansainvälisten ympäristösopimusten kokemiin vastoinkäymisiin sekä näkyy kansallisella tasolla asiantuntijoiden mukaan riittämättömäksi jäävässä ympäristöpoliittisessa ohjauksessa.

\section{Vihreän työn agenda osana ILO:n toimintaa}

Kansainvälinen työjärjestö ILO yhtenä YK:n johtavista toimielimistä työntekijöiden asioissa ei ole ilmeisin mieleen tuleva taho, kun puhutaan kestävyyssiirtymän edistämisestä. Kuitenkin järjestössä on tehty 1970-luvulta alkaen systemaattista työtä työympäristöä laajemman ympäristön huomioimiseksi sekä integroitu ympäristöteemoja järjestön koulutuksiin (Olsen \& Kemter 2012). Historiallisessa katsauksessaan Olsen ja Kemter (2012) kuvaavat, miten ympäristökysymykset ovat näkyneet ILO:n toiminnassa eri vuosikymmenillä. 1980-luvulla ILO:n toimintaan vakiintuivat ympäristöä koskevat teemat, joita olivat muun muassa myrkylliset kemikaalit, ydinjäte, hiilidioksidin määrä ilmakehässä sekä merien saastuminen. ILO oli aktiivinen Rion vuoden 1992 ympäristö- ja kehityskonferenssin sekä Johannesburgin 
vuoden 2002 kestävän kehityksen konferenssin valmisteluissa ja vaikutti osaltaan siihen, että työntekijöiden oikeudet mainittiin konferenssien päätöslauselmissa. Kestävä siirtymä tuli mukaan käsitteenä 2000-luvulla (Olsen \& Kemter 2012). Tällöin alettiin korostaa tarvetta kiireellisille toimenpiteille ilmastonmuutoksen hillitsemiseksi ja siirtymän toteuttamiselle oikeudenmukaisesti.

Vihreän työn aloite sai alkunsa ILO:n, Yhdistyneiden kansakuntien ympäristöohjelman (UNEP:n), Kansainvälisen työnantajajärjestön (IOE:n) ja Ammattiyhdistysliikkeen maailmanjärjestön (ITUC:n) yhteistyönä vuonna 2007. ILO:n tuolloinen pääjohtaja Juan Somavia ehdotti Kansainväliselle työkonferenssille, että oikeudenmukainen siirtymä vihreisiin töihin nostettaisiin yhdeksi ILO:n keskeisistä painopistealueista. Ensimmäinen vihreää työtä ja oikeudenmukaista siirtymää käsitellyt laaja raportti Green jobs - Towards decent work in sustainable, low carbon world julkaistiin vuonna 2008 yhteistyössä UNEP:n kanssa. Vuonna 2009 perustettiin ILO:n sisäinen vihreiden töiden ohjelma (Green Jobs Programme). Vuonna 2013 oikeudenmukaista siirtymää tukemaan perustettiin myös ILO:n vihreä aloite (Green initiative), jonka tavoitteena on tarjota eri toimijoille työkaluja vihreän siirtymän toteuttamiseen. Näin vihreä työ ja vihreät työpaikat nostettiin keskeiseen asemaan, yhdeksi ILO:n seitsemästä satavuotisjuhla-aloitteesta. Vihreiden töiden ohjelmalla ja vihreällä aloitteella ILO pyrkii samanaikaisesti edistämään sekä YK:n vuosituhattavoitteita että reilun työn agendaa (Decent Work Agenda). Lisäksi vihreä työ on ollut keskeisesti esillä ILO:ssa vuonna 2017 perustetussa Maailmankomissiossa (Global Comission on the Future of Work), jonka tavoitteena on luoda edellytykset tulevaisuuden oikeudenmukaiselle ja kestävälle työelämälle. Siksi olemme ottaneet tarkasteluun myös maailmankomission tutkimuspaperisarjassa vuonna 2018 julkaistun artikkelin The future of work in a changing natural environment: Climate change, degradation and sustainability.

\section{ILO:n vihreän työn raportit}

Keskitymme tarkastelemaan sellaisia vihreää työtä käsitteleviä raportteja, joiden tuottajana, tuottajakumppanina tai tilaajana on ollut ILO ja, vuoden 2008 jälkeen, ILO:n vihreän työn osasto, ohjelma tai aloite. Tiedossamme on 11 tällaista raporttia, tutkimuspaperia tai ohjelmakuvausta. Tarkasteltavat raportit on lueteltu taulu- 
kossa 1. Osa raporteista pureutuu kattavasti ja laajasti vihreän työn tematiikkaan ja edistämiseen (ILO 2008; 2012; 2018a). Osa on lyhyempiä katsauksia vihreän työn ohjelmaan ja sen saavutuksiin (ILO 2016) tai eri toimijoiden toiminnan avuksi suunnattuja ohjeistuksia tai suosituksia (ILO 2015; 2018b; 2018c). Vuosien 2011 ja 2019 laajat raportit (ILO 2011; 2019) keskittyvät ammattitaito- ja osaamisvaatimuksiin ja niiden ennakointiin. Lisäksi ILO:lla on lukuisia maakohtaisia vihreän työn raportteja, mutta ne olemme jättäneet tarkastelun ulkopuolelle. ILO:n tutkimustyö on mittavaa, mutta raportit voivat olla vaikeasti löydettävissä haarautuvilta ja eri alaorganisaatioiden ylläpitämiltä verkkosivuilta.

Artikkelia varten luimme raportit useaan kertaan ja listasimme niissä toistuvia keskeisiä teemoja ja trendejä. Lukemisen perusteella muodostimme kuusi kattoteemaa, jotka esittelemme seuraavaksi.

\section{ILO:n raporttien keskeiset teemat}

Kaikkia vuosina 2008-2019 julkaistuja raportteja yhdistävät seuraavat keskeiset teemat ja tavoitteet: a) kestävyyssiirtymän tarpeellisuuden perustelu; b) ilmastonmuutoksen vaikutukset työn maailmaan; c) kestävyyssiirtymien vaikutukset työllisyyteen ja työn maailmaan; d) vihreän työn määrittely ja sen potentiaalin kuvaus; e) keinot ja toimenpiteet vihreän työn luomiselle ja kestävyyssiirtymän edistämiselle. Lisäksi lähes kaikissa raporteissa tarkastellaan f) ammattitaito- ja osaamisvaatimuksien muutoksia. Vuosien 2011 ja 2019 raportit keskittyvät muuttuvien osaamisja ammattitaitovaatimusten ennakointiin. Monessa raportissa esitellään myös jo toteutettuja vihreän työn aloitteita tai kokeiluja.

Ensimmäisissä vihreän työn raporteissa painottuu pyrkimys määritellä, mitä ovat vihreät työpaikat. Tämä tarve korostui vuoden 2008 talouskriisin jälkeen, jolloin eri valtiot toteuttivat kansallisia vihreän kasvun tai työllisyyden ohjelmia, joilla pyrittiin samanaikaisesti kasvattamaan työllisyyttä ja rahoittamaan siirtymiä esimerkiksi uusiutuviin energiamuotoihin. Vihreän työn määrittely ja tilastollinen seuranta oli ajankohtaista, jotta pystyttäisiin määrittelemään, ovatko toteutetut politiikkatoimet synnyttäneet työpaikkoja. Aluksi vihreän kasvun ja vihreiden töiden ohjelmien ympärillä käyty keskustelu pyöri pitkälti sen ympärillä, luoko vihreä talous työllisyyttä (ILO 2012, 6). Lisäksi voidaan ajatella, että ILO:n tavoittelema työllisyys- ja 
Taulukko 1. ILO:n vihreän työn raportit sekä ohjelma- ja tutkimuspaperit 2008-2019.

\begin{tabular}{|c|c|c|c|c|c|}
\hline Raportti & Vuosi & Sivuja & $\begin{array}{l}\text { Julkaisurarja/ } \\
\text { julkaisusyy }\end{array}$ & Painopiste & Taustaorganisaatiot/taustaohjelmat \\
\hline $\begin{array}{l}\text { Green jobs: Towards decent } \\
\text { work in a sustainable, } \\
\text { low-carbon world }\end{array}$ & 2008 & 378 & & $\begin{array}{l}\text { Vihreän työn määrittelyä, } \\
\text { työllisyysvaikutusten arviointia eri } \\
\text { toimialoilla, ennusteita ja suosituksia. }\end{array}$ & $\begin{array}{l}\text { Tilaajana Vihreän työn aloite (Green Jobs } \\
\text { Initiative), sis. UNEP, ILO, IOE ja ITUC ja } \\
\text { laatijana the Worldwatch Institute, } \\
\text { avustajana the Cornell University Global } \\
\text { Labor Institute avustamana. }\end{array}$ \\
\hline $\begin{array}{l}\text { Skills for green jobs: } \\
\text { A global view. Synthesis report } \\
\text { based on } 21 \text { country studies. }\end{array}$ & 2011 & 472 & $\begin{array}{l}\text { Vuoden } 2008 \\
\text { Green jobs } \\
\text {-raportin } \\
\text { löydökset ja } \\
\text { vihreän työn aloite }\end{array}$ & $\begin{array}{l}\text { Vihreisiin töihin liittyvien osaamis- ja } \\
\text { ammattitaitovaatimusten kartoitus. } \\
\text { Yhteisraportti } 21 \text { toteutetusta } \\
\text { maakohtaisesta tarkastelusta. }\end{array}$ & $\begin{array}{l}\text { Kirjoittajat Strietska-Ilina, Hoffmann, } \\
\text { Durán Haro, Jeon. } \\
\text { Skills and Employability Department, } \\
\text { Job Creation and Enterprise Development } \\
\text { Department. }\end{array}$ \\
\hline $\begin{array}{l}\text { Working towards sustainable } \\
\text { development: Opportunities } \\
\text { for decent work and social } \\
\text { inclusion in a green economy }\end{array}$ & 2012 & 209 & & $\begin{array}{l}\text { Eritelty vihertymisen vaikutuksia eri } \\
\text { toimialoilla, kuten maatalous, metsäala, } \\
\text { kalastus, energia, teollinen valmistus, } \\
\text { kierrätys, rakentaminen ja kuljetus. }\end{array}$ & $\begin{array}{c}\text { Vihreän työn aloite (Green Jobs Initiative) ja } \\
\text { ILO:n kansainvälinen työelämätutkimuksen } \\
\text { instituutti (the International Institute for } \\
\text { Labour Studies of ILO). }\end{array}$ \\
\hline $\begin{array}{l}\text { Sustainable development, } \\
\text { decent work and } \\
\text { green jobs }\end{array}$ & 2013 & 120 & $\begin{array}{l}\text { International } \\
\text { Labour } \\
\text { Conference } \\
\text { 102nd Session }\end{array}$ & $\begin{array}{c}\text { Kansainvälisessä työkonferenssissa } \\
\text { käsiteltiin kestävän kehityksen ja reilun } \\
\text { työn mukanaan tuomia mahdollisuuksia } \\
\text { ja haasteita. }\end{array}$ & ILO \\
\hline $\begin{array}{l}\text { Guidelines for a just transition } \\
\text { towards environmentally } \\
\text { sustainable economies and } \\
\text { societies for all }\end{array}$ & 2015 & 23 & $\begin{array}{l}\text { Komitea- } \\
\text { työskentelyn } \\
\text { dokumentointi }\end{array}$ & $\begin{array}{l}\text { Suosituksia siihen, miten hallitukset ja } \\
\text { muut yhteiskunnalliset toimijat voivat } \\
\text { toteuttaa kestävyyssiirtymää. }\end{array}$ & $\begin{array}{l}\text { Kolmikantainen komiteatyöskentely, } \\
\text { jossa edustajia eri maiden hallituksista sekä } \\
\text { työnantaja- ja työntekijäorganisaatioista. }\end{array}$ \\
\hline $\begin{array}{l}\text { Green jobs progress } \\
\text { report 2014-2015 }\end{array}$ & 2016 & 46 & & $\begin{array}{l}\text { Vihreän työn ohjelman } \\
\text { kolmas seurantaraportti. }\end{array}$ & ILO \\
\hline Greening with jobs & $2018 a$ & 189 & $\begin{array}{l}\text { World } \\
\text { employment and } \\
\text { social outlook }\end{array}$ & $\begin{array}{l}\text { Osa ILO: } \mathrm{n} \text { vihreän aloitteen } \\
\text { (Green Initiative) toimeenpanoa. }\end{array}$ & ILO \\
\hline $\begin{array}{l}\text { The employment impact of } \\
\text { climate change adaptation }\end{array}$ & $2018 b$ & 40 & $\begin{array}{l}\text { Input Document } \\
\text { for the G20 } \\
\text { Climate } \\
\text { Sustainability } \\
\text { Working Group }\end{array}$ & $\begin{array}{l}\text { Tuotettu Argentiinan puheenjohtamaa } \\
\text { G20-kokousta varten. }\end{array}$ & ILO \\
\hline $\begin{array}{l}\text { Just transition towards } \\
\text { environmentally sustainable } \\
\text { economies and societies } \\
\text { for all }\end{array}$ & $2018 c$ & 22 & $\begin{array}{l}\text { ILO ACTRAV } \\
\text { Policy Brief }\end{array}$ & $\begin{array}{l}\text { Katsaus ilmastonmuutoksen } \\
\text { ja työn yhteyksiin. }\end{array}$ & $\begin{array}{l}\text { Bureau for Workers' Activities } \\
\text { (ACTRAV), ILO }\end{array}$ \\
\hline $\begin{array}{l}\text { The future of work } \\
\text { in a changing natural } \\
\text { environment: Climate change, } \\
\text { degradation and sustainability }\end{array}$ & $2018 d$ & 48 & $\begin{array}{l}\text { ILO Future of } \\
\text { Work Research } \\
\text { Paper Series }\end{array}$ & $\begin{array}{l}\text { Tutkimuspaperisarja on tarkoitettu } \\
\text { Maailmankomission työn tueksi näiden } \\
\text { muotoillessa raporttia työn } \\
\text { tulevaisuudesta vuoden } 2019 \\
\text { kansainväliseen työkonferenssiin. } \\
\text { Tutkimuspaperi esittää, että } \\
\text { luonnonympäristö on huomioitava työn } \\
\text { tulevaisuudesta keskusteltaessa. }\end{array}$ & $\begin{array}{l}\text { Guillermo Montt and Federico Fraga } \\
\text { (ILO Research Department). } \\
\text { Marek Harsdorff } \\
\text { (ILO Green jobs Unit). }\end{array}$ \\
\hline $\begin{array}{l}\text { Skills for a greener future: } \\
\text { A global view. Based on } \\
32 \text { country studies. }\end{array}$ & 2019 & 226 & & $\begin{array}{c}\text { Vihreä siirtymä } \\
\text { ja ammattitaitomuutokset. }\end{array}$ & $\begin{array}{l}\text { Skills and Employability Branch } \\
\text { of the Employment Policy Department \& } \\
\text { Green Jobs Programme of the Enterprises } \\
\text { Department \& Research Department. }\end{array}$ \\
\hline
\end{tabular}


ilmastopolitiikan yhtäaikainen edistäminen vaati edistettävien ilmiöiden vakiinnuttamista tiettyihin käsitteisiin, joilla haluttua muutosta voitiin kuvata.

Ensimmäisissä raporteissa vihreä työ määriteltiin laveasti (ILO 2013, 23): “Any decent job that contributes to preserving or restoring the quality of the environment, be it in agriculture, industry, services or administration." Huomionarvoista määrittelyssä on, että se painottaa ekologisen kestävyyden lisäksi työn reiluutta tai ihmisarvoisuutta (decent work). Vuoden 2012 raportissa vihreän työn ulottuvuuksia tarkennetaankin kuviolla, joka tekee eron vihreisiin ammatteihin, työpaikkoihin vihreillä teollisuuden aloilla sekä ihmisarvoisiin töihin. Vihreät työpaikat ovat ILO:n määritelmän mukaan työpaikkoja, jotka ovat joko ihmisarvoisia vihreitä ammatteja vihreillä aloilla, ihmisarvoisia töitä vihreillä aloilla tai ihmisarvoisia vihreitä ammatteja millä tahansa alalla (ILO 2012, 7). Sen sijaan ei-ihmisarvoiset vihreiden alojen työt tai vihreät ammatit eivät ole ILO:n määritelmän mukaista vihreää työtä.

Käytännössä vihreän työn määrittely on osoittautunut ongelmalliseksi. Yhdysvalloissa heräsi toteutettujen vihreän talouden ja vihreän työn ohjelmien seurauksena laajasti kritiikkiä vihreän työn käsitteen epämääräisyydestä sekä siitä, että todellisuudessa ohjelmat johtivat työpaikkojen siirtymiseen ulkomaille (Pollin 2009; Furchtgott-Roth 2012). Furchtgott-Roth (2012) kiinnittää huomiota siihen, miten yritykset tilastoida vihreää työtä tekeviä johtivat useilla aloilla absurdeihin lopputuloksiin. Esimerkiksi maissia ruoaksi viljeleviä maanviljelijöitä ei katsottu vihreän työn tekijöiksi, mutta jos maissi hyödynnettiin biopolttoaineeksi, työ katsottiin vihreäksi työksi. Myöhemmissä raporteissa määrittely on jäänyt taka-alalle. Sen sijaan korostetaan, että vihreää työtä voi löytyä miltä alalta tahansa ja että kaikissa ammateissa voi edistää kestävyyttä.

Tavoiteltavan kestävyyssiirtymän oikeudenmukaista luonnetta on korostettu ottamalla työn keskeiseksi painopisteeksi oikeudenmukainen siirtymä (just transition). Jo vuoden 2008 ensimmäisessä raportissa pyrittiin kuvaamaan, mitä ILO tarkoittaa oikeudenmukaisella siirtymällä. ILO:n mallissa oikeudenmukaisuuden takuuna on se, että oikeudenmukaisen siirtymän kehyksen suunnittelussa on mukana edustajia ammattiliitoista, kansallisesta ja paikallisesta hallinnosta, edelläkävijäyrityksistä (kestävyyden näkökulmasta) sekä paikallisyhteisöistä. Siirtymää toteutettaessa on ymmärrettävä, että se vaikuttaa suuresti työntekijöiden ja yhteisöjen elämään. Sosiaalisen solidaarisuuden nimissä onkin kehitettävä poliittista ja työpaikkatasoista tukea sekä huolehdittava siitä, että siirtymässä häviävät saavat toi- 
meentulotukea, uudelleenkoulutusmahdollisuuksia, siirtymätukea tai muita mahdollisia tukia. Lisäksi oikeudenmukaiseen siirtymään kuuluu globaalin oikeudenmukaisuuden näkökulman huomiointi. Raportissa tunnustetaan, että oikeudenmukaisesta siirtymästä on olemassa vain vähän käytännön esimerkkejä ja että haaste on valtava (ILO 2008, 27-28).

Seuraavaksi keskitymme tarkemmin kahteen keskeiseen teemaan raporteissa: 1) ilmastonmuutos ja 2) siirtymän vaikutukset työhön ja työllisyyteen. Ilmastonmuutos on julkisessa keskustelussa noussut kokoavaksi yleiskäsitteeksi puhuttaessa ekologisesta kriisistä ja sen ratkaisuista, vaikka se ei teknisesti kata esimerkiksi lajikatoa. ILO:n raporttien tarkastelu auttaa ymmärtämään työelämän muutoksia edessä olevia välttämättömiä kunnianhimoisia ilmastotavoitteita ja -toimenpiteitä toteutettaessa. Tässä prosessissa harva tuskin vastustaa oikeudenmukaista siirtymää käsitteenä, mutta sen toteutus on poliittisten kiistojen kohde. Siksi katsomme, että näiden teemojen ymmärtäminen on ajankohtaista suomalaiselle työelämälle ja sen tutkimukselle. Eriteltyämme kestävyysajattelua ILO:n vihreän työn raporteissa palaamme siihen, mitä suomalaisessa työelämän tutkimuksessa on jo tehty ja tehdään näiden teemojen tarkemmaksi kartoittamiseksi.

\section{Miten ilmastonmuutos muuttaa työtä?}

Kaikkien ILO:n raporttien lähtökohtana on lisääntynyt ymmärrys siitä, että ilmastonmuutos ja sen aiheuttamat vaikutukset elinympäristöissä vaikuttavat jo raportin kirjoittamishetkellä - ja jatkossa yhä enemmän - työpaikkoihin, työllisyyteen ja työn tekemiseen. Kiinnostavaksi kysymykseksi nouseekin se, miten teeman käsittely muuttuu vuosien 2008-2019 välillä ilmastonmuutoksen seurausten muuttuessa yhä ilmeisemmiksi.

Vuoden 2008 raportissa ilmastonmuutoksen vaikutukset työpaikkoihin ovat maininnan tasolla, kun raportti varsinaisesti keskittyy kuvaamaan eri aloille syntyviä uudenlaisia vihreitä työpaikkoja sekä arvioimaan näiden määrää ja laatua. Ilmastonmuutoksen kerrotaan vaikuttavan jo tuolloin työpaikkojen määrään esimerkiksi maa- ja kalatalouden piirissä, erityisesti kehittyvissä maissa. Vuoden 2012 ja 2013 raporteissa käsitellään paitsi erilaisten ympäristöongelmien sosiaalisia seurauksia ja taloudellisia vaikutuksia myös hurrikaani Katarinan ja Sidr-syklonin jo aiheuttamia työpaikkojen menetyksiä (ILO 2012, 5-6). Tarkkojen työelämään 
kohdistuvien vaikutusten kuvaamisen sijaan pääpaino on kuitenkin business as usual -skenaarion yleisemmän kestämättömyyden kuvauksessa. Vuoden 2018 aikana julkaistuissa raporteissa kuvataan jo huomattavasti yksityiskohtaisemmin ilmastonmuutoksen vaikutuksia työn maailmaan. Nostamme tässä esiin seuraavat asiat:

1. Ilmastonmuutoksen seuraukset johtavat työvuosien menetyksiin. ILO:n raporttien mukaan vuosien 2000-2015 välillä 23 miljoonaa työelämävuotta on menetetty vuosittain ihmisten aiheuttamien tai voimistamien ympäristökatastrofien seurauksena (ILO 2018b, 14). Nämä luvut kattavat ihmisen aiheuttamat teollisuusonnettomuudet ja voimistuneet luonnonkatastrofit, kuten syklonit. Työpaikkoja ja työterveyttä uhkaavat lisäksi paikalliset ympäristöongelmat, kuten ihmisen aiheuttamat ilman, veden, ruokaketjujen tai maaperän pilaantuminen sekä biodiversiteettikato. Riskit muuttuvat katastrofeiksi, kun ne ylittävät paikallisen kantokyvyn pakottaen ihmiset muuttamaan tai romuttaen infrastruktuurin ja taloudellisen toiminnan edellytykset (ILO 2018a, 22-23).

2. Lämpötilan nousun vaikutus työterveyteen ja turvallisuuteen sekä työn tuottavuuteen. ILO:n arvioiden mukaan jopa optimistisemmissa 1,5 asteen lämpenemisen skenaarioissa työtuntien määrän arvioidaan kutistuvan 1,9 prosenttia G20maissa vuoteen 2030 mennessä lämpötilan nousun seurauksena (ILO 2018b, 16-17). Erityisen haavoittuvaisia ovat ulkona työskentelevät työntekijät.

3. Ilmastonmuutos ja muut ihmisen aiheuttamat ympäristöongelmat hävittävät työpaikkoja vaarantamalla ekosysteemipalvelut. ILO:n arvioiden mukaan maailmassa on kaikkiaan 1,5 miljardia suoraan ekosysteemipalveluista riippuvaista työpaikkaa. Niitä on esimerkiksi seuraavilla aloilla: maa- ja metsätalous, kalatalous, ruoka-, juoma- ja tupakkateollisuus, metsä- ja paperiteollisuus, biopolttoaineteollisuus, uusiutuvat energialähteet, monet lääke- ja kemianteollisuuden alat sekä turismin muodot (ILO 2018a, 20-21; ILO 2018b, 17). Työpaikkoja alkutuotannossa uhkaavat myös muuttuvat sääolosuhteet ja veden kierto (ILO 2018b, 24).

Vuoden 2018 Greening with jobs -raportti (2018a, 18-19) korostaa, että vain harvat maat ovat onnistuneet irtikytkemään työllisyyden ja kasvihuonekaasupäästöjen kasvun toisistaan. Globaalisti työllisyyden kasvu onkin kytkeytynyt kasvihuonekaasujen lisääntymiseen ja luonnonvarojen lisääntyneeseen käyttöön. Työllisyyden 
ylläpidon laskettiin tuottaneen vuonna 2014 selvästi enemmän kasvihuonekaasuja ja olleen myös selvästi materiaali-intensiivisempää kuin vuonna 2000.

ILO:n raportit tuovat esiin, että ilmastonmuutoksella ja muilla ihmisen aiheuttamilla ympäristöongelmilla on erilaisia seurauksia eri puolilla maailmaa eri työntekijäryhmille. Eniten ilmastonmuutoksesta tulevat kärsimään köyhimmät, alkutuotannosta riippuvaiset työntekijät, naiset sekä saarivaltioissa asuvat (ILO 2018a, 25). Kuten ILO:n selvitykset osoittavat, ympäristön tilan heikkeneminen lisää entisestään eriarvoisuutta maiden sisällä ja välillä (ILO 2018d, 11). Viimeisimmissä raporteissa tuodaan esille, että työllisyyden kasvattaminen ympäristön tilaa heikentävillä tavoilla vaikeuttaa samalla mahdollisuuksien tasa-arvon toteutumista (ILO 2018a, 28).

\section{Siirtymä vähähiilisyyteen muuttaa työn maailmaa}

Ilmastonmuutoksen suoria vaikutuksia kattavampi teema ILO:n raporteissa on kestävyyssiirtymän työllisyysvaikutukset. Kaiken kaikkiaan raporttien keskeisenä tavoitteena on vihreän talouden tai ilmastopolitiikan edistäminen työelämä ja työllisyys huomioiden. Työllisyys- ja ilmastopolitiikka yhdistyvät raporteissa vihreän kasvun teemojen alle, ja huomio kiinnittyy myös siirtymän oikeudenmukaisuuteen.

Jo ILO:n ensimmäinen vihreän työn raportti Green jobs report (2008) esittää, että työllisyys ja työpaikat siirtyvät yhä enemmän vihreän talouden aloille. Raportin tavoitteena on luoda katsaus siihen, miten siirtymä kestävyyteen vaikuttaa työpaikkoihin. Raportti tiivistää vaikutukset seuraavasti: Ensinnäkin joillakin aloilla arvioidaan syntyvän lisää työpaikkoja, kun näillä aloilla ilmenee tarvetta uusille kestävän kehityksen osaamiseen nivoutuville työtehtäville. Toiseksi työpaikkoja tulee siirtymään alalta toiselle tai työ korvataan uusilla ja kestävämmillä työpaikoilla, esimerkiksi silloin kun energia-alalla siirrytään fossiilisista uusiutuviin energiamuotoihin. Kolmanneksi joiltakin aloilta häviää työpaikkoja, jotka eivät korvaudu uusilla, kun kestämättömiä teollisuudenaloja joudutaan ajamaan alas. Neljänneksi monet työpaikat muuttuvat ja uudelleen määrittyvät kestäviksi työpaikoiksi vähitellen, kun alalla tarvittavat taidot, työmenetelmät ja työprofiilit vihertyvät asteittain (ILO 2008, 3).

ILO:n raporteissa esitetään, että työpaikkoja syntyy vihreän rakennemuutoksen ansiosta enemmän kuin niitä siirtymässä menetetään (ILO 2011; 2019). Joillakin 
aloilla tullaan kuitenkin kokemaan työpaikkojen mittavaa katoamista, ja muutosten arvioidaan osuvan erityisesti matalan koulutus- ja osaamistason töihin. Juopa taidoissa (skills gaps) sektorien välillä voi aiheuttaa rakenteellista työttömyyttä. Vuoden 2018(a) raportissa tarkastellaan erikseen siirtymään liittyvien eri kehityskulkujen työllisyysvaikutuksia. Business as usual -skenaarioon verrattuna siirtymä hiilineutraaleihin energiamuotoihin luo globaalisti arviolta 18 miljoonaa uutta työpaikkaa. Tämän lisäksi siirtymän kiertotalouteen arvioidaan luovan 6 miljoona uutta työpaikkaa verrattuna neitseellisten luonnonvarojen hyödyntämiseen. Myös kestävään maatalouteen siirtymisellä arvioidaan olevan myönteisiä työllisyysvaikutuksia.

Vihreän työn osaston lisäksi myös ILO:n muut osastot ovat aktiivisesti osallistuneet vihreiden töiden ohjelman toteuttamiseen. Keskeisessä roolissa on ollut erityisesti Skills and Employability Department / Branch, joka on toteuttanut globaalia tutkimusohjelmaa kartoittaakseen tulevaisuuden vihreissä talouksissa tarvittavaa ammattitaitoa (ILO 2011, v, 3).

Ammattitaitoa tarkastelevien raporttien pääviesti on, että järjestelmällisellä osaamisen kehittämisellä voidaan tukea siirtymää kestävyyteen. Sekä ammattiin opiskelevia että työikäisiä tulisi kouluttaa niin, että heillä on tarvittavat taidot hyödyntää uusia teknologioita, ymmärtää ympäristölainsäädäntöä sekä siirtyä uusiutuviin energiamuotoihin. Jo 2010-luvun alussa tuotetuissa maaraporteissa todettiin, että osaamisen puute vaikeuttaa vihreämpään talouteen siirtymistä (ILO 2011). Ennakoivalla ja eri työelämäosapuolten kanssa dialogissa suunnittelulla koulutuspolitiikalla valtiot voivat varmistaa, että työntekijöillä on tulevaisuudessa tarvittava ammattitaito. Vuoden 2011 raportin mukaan jatkossa jokaisessa ammatissa tarvitaan ymmärrystä kestävyydestä. Vihreän rakennemuutoksen katsotaankin vaikuttavan koko koulutusjärjestelmään kaikilla koulutusasteilla (ILO 2011, xxv).

\section{Heikko ja vahva kestävyysajattelu ILO:n vihreän työn raporteissa}

Tässä osiossa tarkastelemme, miten ILO:n raporteissa näkyy aikaisemmassa tutkimuksessa tunnistettu jaottelu heikkoon ja vahvaan kestävyysajatteluun (Räikkönen 2011; Johansson \& Henriksson 2020). Samalla tarkastelemme, miten raportit sekä 
vahvistavat että haastavat heikkoon kestävyysajatteluun perustuvalle ekologiselle modernisaatiolle ominaisia ratkaisuja ja puhetapoja.

ILO:n raporttien keskiössä on ilmastonmuutoksen kielteisten työelämävaikutusten kuvaaminen. Tämä painotus voidaan nähdä yrityksenä haastaa julkisessa keskustelussa pitkään vallalla ollut asetelma, jonka mukaan ympäristönsuojelu tai ilmastopolitiikka uhkaavat taloutta ja erityisesti työpaikkoja, eli niin kutsuttu "ympäristö vastaan työpaikat" -asetelma (Nugent 2010; Felli 2014). Raporttien keskeisenä tavoitteena tuntuu olevan tämän asetelman kääntäminen päälaelleen: sekä työpaikkoja että työterveyttä ja -hyvinvointia uhkaa ilmastopolitiikan sijaan ilmastonmuutos. Lisäksi työpaikkoja uhkaa sama trendi, joka vahvistaa ilmastonmuutosta, eli työn globalisaatio ja markkinatalouden vahvistuminen.

ILO:n vihreän työn ohjelmalle ja puhetavan muutokselle on aikaisemman tutkimuksen valossa tarvetta ja tilausta. Vaikka ammattiyhdistysliike ja ILO ovat olleet mukana kansainvälisissä ympäristösopimuksissa ja niiden valmistelussa jo 1970luvun ensimmäisistä ympäristökokouksista lähtien (Olsen \& Kemter 2012), ovat ammattiliitot niin kansainvälisesti kuin kansallisella tasolla usein asettuneet vastustamaan tiukempaa ympäristö- ja ilmastopolitiikkaa juuri työpaikkojen menettämisen pelossa (Felli 2014). Raporteissaan ILO pyrkii rakentamaan kuvaa ilmastonmuutoksesta järjestön perinteistä työkenttää eli työterveyttä, työturvallisuutta ja ihmisarvoista työtä vaarantavana ilmiönä, jonka ratkaisu kuuluu olennaisesti niin ILO:n kuin muidenkin työntekijöiden etuja ajavien toimijoiden tehtäväsarkaan.

Ilmastonmuutoksen työelämävaikutusten lisäksi ILO:n raporteissa kuvataan laajasti sitä, miten siirtymä kestävään yhteiskuntarakenteeseen vaikuttaa työn maailmaan. Raportit tuntuvat rakentuvan aikaisemmassa tutkimuksessa yleisesti tunnistetulle puhetavalle eli ekologisen modernisaation reformistiselle "vihreän talouden" lupaukselle (Ewing 2017). Vihreän kasvun ja kestävyyteen kohdistuvien investointien kuvataan tuottavan enemmän uusia työpaikkoja kuin kestävyyssiirtymässä menetetään. Erityisesti 2000-luvun ensimmäisellä vuosikymmenellä kirjoitetuissa raporteissa vihreä kasvu kuvataan ratkaisuna vuoden 2008 talouskriisiin jälkeiseen talouden taantumaan.

ILO:n raporttien tapa kuvata työelämän muutoksia siirryttäessä vihreään talouteen poikkeaa kuitenkin jossakin määrin tavasta, jolla ekologista modernisaatiota aikaisemmassa tutkimuksessa kuvataan. Aktiivisina toimijoina eli siirtymän toteuttajina ILO:n raporteissa näyttäytyvät nimittäin - kuluttajien, markkinoiden ja 
yritysten sijaan tai rinnalla - valtiot lainsäädäntöroolissa, erilaiset taloutta ohjaavat instituutiot sekä myös työntekijät ja ammattiyhdistysliike työntekijöiden edustajana. Raportit vaikuttavat rakentuvan ekologisen modernisaation heikon tai reformistisen kestävyysajattelun varaan mutta taktisesti yhdistäen vihreän kasvun ajatusta ILO:lle perinteisesti lähellä oleviin työntekijöiden oikeuksia ja osallisuutta korostaviin puhetapoihin. Siksi varsinkin ensimmäisissä vihreiden töiden raporteissa olennaista on vihreän työn määrittely töiksi, jotka ovat ihmisarvoisia tai reiluja, lisäävät hyvinvointia ja ovat tekijöilleen turvallisia (Di Ruggiero ym. 2015).

Ihmisarvoisen työn vaateen saaminen mukaan ympäristöneuvotteluihin oli pitkään ILO:n agendalla ympäristö- ja ilmastokonferensseissa. Ilmastonmuutos ja siirtymä kestävyyteen näyttäytyvätkin raporteissa tapana nostaa työelämän ongelmat ja työntekijöiden oikeudet keskeisempään rooliin käsillä olevan siirtymän toteuttamiseksi oikeudenmukaisesti. Uusliberalistisen politiikan vallitessa juuri ILO:n edustamat intressit ovat tunnistetusti jääneet markkinatalousajattelun jalkoihin ja menettäneet asemiaan (Standing 2009). Alleviivaamalla oikeudenmukaisen siirtymän tarvetta ILO:n raportit nostavat yritysten ja kuluttajien sijaan keskeisiksi toimijoiksi työelämän toimijat ja asiantuntijat sekä erilaisiin instituutioihin kytkeytyvät päätöksentekijät, kuten ILO itse, sekä ILO:n intressejä lähellä olevat toimijat.

Heikolle kestävyysajattelulle tyypillinen vihreän talouden lupaus on ILO:n raporteissa keskeinen argumentti. ILO:n vihreän työn ohjelmat ovat osa laajempaa vuoden 2008 laman jälkeen virinnyttä vihreän talouden ja vihreiden töiden keskustelua. Vihreän kasvun kautta syntyvät vihreät työpaikat ovat kuitenkin vain yksi tapa hahmotella työn roolia vähähiilisessä tulevaisuudessa (Bottazzi 2020). Vuoden 2008 jälkeen yleistyi myös nykymuotoisen talousjärjestelmän kritiikki, joka on saanut monia muotoja. Yksi niistä on vahvaa kestävyysajattelua edustava degrowth-liike ja -tutkimus, joka kyseenalaistaa talouskasvun ekologisen ja sosiaalisen kestävyyden (Honkasalo 2012; Kasvio 2014; Joutsenvirta ym. 2016). Degrowth-tutkimuksella on yhteys ekologiseen taloustieteeseen, joka kyseenalaistaa sen, onko jatkuvaa talouskasvua mahdollista ylläpitää maapallon rajallisten ekologisten reunaehtojen puitteissa (D'Alisa ym. 2014). Kestävä kasvu perustuukin ajatukselle talouskasvun ja sen kielteisten ympäristövaikutusten irtikytkennästä. Tämä on teema, jota myös ILO:n raportit käsittelevät (ILO 2018a). Useimmissa raporteissa esitetään, että talouskasvun ja kielteisten ympäristövaikutusten irtikytkentä on mahdollista, vaikkakin haasteellista. Vuonna 2018 julkaistu työn tulevaisuutta käsittelevä tutkimuspaperi (ILO 
2018d) nojautuu kuitenkin muita raportteja voimakkaammin ekologiseen taloustieteeseen ja esittää, että talous tulisi nähdä ekosysteemin alasysteeminä ja sopeuttaa sen toiminta nopeasti ekologisiin raja-arvoihin. Onkin nähtävissä, että erityisesti myöhemmissä vihreän työn raporteissa on heikkoa kestävyysajattelua kriittisempiä tai syvänvihreämpiä sävyjä, jotka alleviivaavat edessä olevan muutoksen radikaaliutta ja vaikeutta. Esimerkiksi vuoden 2018 Greening with jobs -raportissa (2018a, 18-19) todetaan, että vain harvat maat ovat onnistuneet kytkemään työllisyyden ja kasvihuonekaasupäästöjen kasvun irti toisistaan. Pääasiassa raportit rakentuvat kuitenkin vihreän talouden ja vihreiden työpaikkojen lupauksille. Lupaukset työpaikkojen synnystä esitetään niitä kyseenalaistamatta, vaikka vihreän talouskasvun epäilijät suhtautuvat lupauksiin kriittisesti (Michaels \& Murphy 2009; Furchtgott-Roth 2012).

Toisin kuin monet vahvaan kestävyysajatteluun nojautuvat akateemiset tai työn roolia kriittisesti tarkastelevat yhteiskuntatieteelliset perinteet vihreän työn raportit eivät pureudu palkkatyön keskeisyyteen nyky-yhteiskunnissa (ks. esim. Standing 2009; Bottazzi 2019). Työn ja talouden tutkijat ovat kuitenkin jo pidempään korostaneet, että palkkatyö on yksi työn muoto muiden joukossa. Yhteiskuntien toiminta rakentuu myös vaihtoehtoiselle työlle, kuten itsensä työllistämiselle, ja palkattomalle työlle, kuten vapaaehtoistyölle ja palkattomalle hoivatyölle (Gibson-Graham ym. 2019). Esimerkiksi Guy Standing (2009) on kuvannut, miten ILO on keskittynyt ajamaan palkkatyösuhteessa olevien työntekijöiden etuja ja ylipäänsä rakentamaan palkkatyöyhteiskuntaa. Siksi muut työn muodot ovat jääneet käsittelemättä tai kokonaan tunnistamatta työksi (Standing 2009, 35). ILO:n raporteissa pääasiallisena huolena onkin perinteisesti työpaikkojen määrä ja palkkatyön ulkopuolelle jääminen. Vahva kestävyysajattelu nostaa esiin kysymyksen siitä, miten ihmisten toimeentulo voidaan turvata niin, että ei ole pakko kasvattaa työllisyyttä ja kokonaiskulutusta (Miller 2019). Universaali perustulo tai hoivatulo voidaan ajatella vastavoimaksi työllisyyttä ja työpaikkojen määrää korostavalle keskustelulle. Näissä malleissa ihmiset saisivat toimeentulonsa osittain tai kokonaan tulosta, joka jaettaisiin kaikille varallisuuteen katsomatta. Myös työtuntien vähentämistä on pidetty yhtenä tapana tehdä kestävyyssiirtymä ja parantaa elämänlaatua aikana, jona työn tuottavuus kasvaa ja yhä uusia aloja automatisoidaan (Bottazzi 2019). ILO:n raporteissakin korostetaan sosiaaliturvaa siirtymävaiheissa, mutta keskeisenä tavoitteena on työllisyyden kasvu vihreän talouden aloilla. 


\section{Vihreän työn tutkimus Suomessa}

Joitakin edellä esiteltyjä ILO:n vihreän työn raporttien teemoja on tutkittu myös Suomessa. Esimerkiksi ilmastonmuutoksen vaikutuksia terveyteen on tutkittu aikaisemmin (Ruuhela ym. 2018) ja tutkitaan parhaillaan Suomen Akatemian rahoittamassa CLIHE-akatemiaohjelmassa. Lisäksi on tarkasteltu ilmastonmuutoksen vaikutuksia esimerkiksi metsätalouteen, porotalouteen ja maatalouteen (Kellomäki ym. 2008; Rasmus ym. 2020). Esimerkiksi Suomessa sademäärän muutokset sekä muutokset talvissa (ml. lumen ja roudan määrän vaihtelut) voivat jatkossa vaikuttaa maa- ja metsätalouteen (Peltonen-Sainio ym. 2016a; 2016b).

Suomalaisessa valtavirtaisessa työelämän tutkimuksessa on kuitenkin toistaiseksi kiinnitetty vain vähän huomiota siihen, miten ilmastonmuutos vaikuttaa maamme elinkeinoihin, työllisyyteen ja työpaikkoihin. Vaikka esimerkiksi Antero Honkasalo, Antti Kasvio ja Timo Räikkönen ovat tehneet avauksia vihreiden töiden ja ilmastonmuutoksen vaikutusten huomioimiseksi (Honkasalo 2012; Kasvio 2014; Räikkönen 2016), muun muassa Työelämän tutkimuspäivillä aihepiiri on ollut aliedustettuna. Kestävyystematiikka on noussut keskiöön monella muulla tutkimusalalla, esimerkiksi kauppatieteissä ympäristö- ja yhteiskuntavastuututkimuksena tai kuluttajatutkimuksessa kiinnostuksena kestäviin elämäntapoihin ja vihreään kuluttajuuteen. Koska työelämän tutkimuksessa kiinnostus on ollut vähäistä, herää kysymys, onko "ympäristöpolitiikka vastaan työpaikat" - asetelma vaikuttanut myös tutkimuskenttään. Ainakin ammatillisten etujärjestöjen toimintaan asetelman katsotaan vaikuttaneen. Suomessa niin julkisessa keskustelussa kuin ammattiyhdistysliikkeen taholta on perinteisesti esitetty, että työntekijöiden on vaikea kannattaa tiukempaa ympäristö- tai ilmastopolitiikkaa, jos tämä lisää entisestään huolta omasta asemasta ja luo epävarmuutta työn jatkumisesta (Räikkönen 2013).

Viime vuosina eri etujärjestöt, kuten Elinkeinoelämän keskusliitto (EK), työntekijäjärjestöt (erityisesti SAK) ja Sitra ovat kuitenkin heränneet tarkastelemaan ilmastonmuutoksen vaikutuksia. Esimerkiksi EK:n konsultointiyritys Deloittella teettämä tutkimus ilmastonmuutoksen vaikutuksista suomalaiseen elinkeinoelämään korostaa, että yhä useamman suomalaisen yrityksen tulisi huomioida ilmastonmuutoksen vaikutukset hankintaketjussaan (Deloitte \& EK 2020). Sitran teettämässä tutkimuksessa puolestaan kiinnitetään huomiota ilmastonmuutoksen seurausten laajaan kirjoon peltoviljelystä masennukseen (Laine ym. 2018). 
Suomesta näyttää siis muutamia poikkeuksia lukuun ottamatta puuttuvan tutkimus, joka käsittelisi työelämän vihertymistä heikon kestävyysajattelun eli ekologisen modernisaation hengessä ja tukisi näin nykyistä ilmastopoliittista tavoitetta eli pyrkimystä saavuttaa hiilineutraalius vuonna 2035 ylläpitäen samalla talouskasvua ja hyvinvointia. Sen sijaan Suomessa on jonkin verran tarkasteltu työelämää, työsysteemejä ja työn merkityksiä nojautuen vahvempaan kestävyysajatteluun esimerkiksi degrowth-tutkimuksesta käsin. Työn roolista ja määritelmästä fossiilitalousjärjestelmän ylläpidossa ja ekososiaalisessa kestävyyssiirtymässä ovat olleet kiinnostuneita erityisesti suomalaiset degrowth- ja kestävyystutkijat (Järvensivu ym. 2012; Järvensivu 2016; Joutsenvirta ym. 2016; Houtbeckers \& Taipale 2017; Lahikainen \& Toivanen 2019). Tutkijoiden vähäiseltä vaikuttavaan kiinnostukseen voi vaikuttaa myös se, millaista tutkimusta Suomessa on päätetty rahoittaa.

Jatkossa tarvitaan yhä enemmän ymmärrystä siitä, miten ilmastokriisin aiheuttamat muutokset ympäristössä vaikuttavat työterveyteen ja -turvallisuuteen. Ymmärtääkseen elinkeinoihin kohdistuvia vaikutuksia työelämän tutkijoiden kannattaa tehdä yhteistyötä muiden alojen tutkijoiden kanssa. Suomessa on eri alojen vähähiilisyystiekarttoja laadittaessa havahduttu siihen, että tarvitaan enemmän ymmärrystä siitä, millaista osaamista siirtymä kestävyyteen vaatii. Tässä voikin työelämän tutkijoilla olla jatkossa työsarkaa; miten siirtymä vaikuttaa työn tekemisen tapoihin ja ammattitaitovaatimuksiin eri aloilla.

\section{Yhteenveto}

Artikkelimme lähtökohtana oli täydentää aikaisemmassa suomalaisessa tutkimuksessa (Hirvilammi ym. 2016; Räikkönen 2016) esitettyä väitettä, että työelämä on keskeisessä roolissa haettaessa ratkaisuja globaaleihin ympäristöongelmiin, kuten ihmisen aiheuttamaan ilmastonmuutokseen ja biodiversiteettikatoon. Lisäksi ilmastonmuutos ja sen hillintä muokkaavat jo nyt työelämää monin eri tavoin. Kansainvälisen työjärjestö ILO:n vihreän työn raportit nostavat kattavasti esiin sekä ilmastonmuutoksen että sen hillinnän vaikutuksia työhön ja työelämään. Raporttien teemat avaavat myös suomalaisille työelämän tutkijoille ja kehittäjille näkökulmia edessä oleviin muutoksiin ja tapoihin, joilla tutkijat ja kehittäjät voivat itse olla mukana rakentamassa oikeudenmukaisen siirtymän edellytyksiä. 
ILO:n vihreän työn raporttien keskeinen viesti on, että oikeudenmukainen siirtymä vihreään talousjärjestelmään luo uusia työpaikkoja ja mahdollisuuksia kehittää työelämästä sosiaalisesti kestävämpää. Näin raportit pyrkivät haastamaan pitkään vallinnutta "ympäristöpolitiikka vastaan työpaikat" -asetelmaa. Keskeistä kestävyyssiirtymän toteutuksessa on vihreän työn raporttien mukaan oikeudenmukaisuus: tarvitaan monenlaista tukea niille aloille ja työntekijöille, joilta työpaikat katoavat siirryttäessä kohti hiilineutraalia kiertotaloutta. Korostaessaan samanaikaisesti vihreää taloutta ja oikeudenmukaista siirtymää ILO:n raportit sekä toisintavat että haastavat valtavirtaistunutta ympäristöpoliittista ajattelutapaa eli heikkoon kestävyysajatteluun nojautuvaa ekologista modernisaatiota. Samalla kun raportit lupaavat siirtymän vihreään talouteen tuovan mukanaan kasvua ja työllisyyttä, ne painottavat markkinatalouden mekanismien sijaan poliittista ohjausta ja työntekijöiden etujärjestöjä keskeisinä toimijoina. ILO:n ansiokkaasta työstä huolimatta raportit ovat palkkatyö- ja ihmiskeskeisiä.

Suomalaisessa työelämän tutkimuksessa keskiössä on ollut työelämän taloudellinen ja sosiaalinen kestävyys. Työelämän tulevaisuutta tarkasteltaessa digitalisaation, johtamisen uusien trendien ja automatisaation kaltaiset muutokset on huomioitu kestävyyssiirtymää kattavammin. Ekologinen kestävyys on siis jäänyt vähemmälle huomiolle. Kuten ILO:n vihreän työn raportit tuovat esille, ilmastonmuutos ja luonnon monimuotoisuuden kaventuminen ovat kuitenkin jo nykyisyyttä. Viimeisissä raporteissa on nähtävissä entistä syvempi huoli tulevaisuudesta. Tuodessaan esille siirtymän kiireellistä tarvetta raportit ovat viime vuosina omaksuneet yhä enemmän vahvan kestävyysajattelun äänenpainoja. Työelämää sekä sen tutkimusta ja kehittämistä tulisi yhä enemmän tarkastella paitsi ylikansallisen myös ylisukupolvisen reiluuden ja lajien välisen oikeudenmukaisuuden näkökulmista.

Esitämme, että ekososiaalisten kriisien herättämien teemojen osaaminen on osa työelämän tutkijoiden tarvitsemaa ammattitaitoa ja yksi keskeinen osaamisalue: tutkijoiden on tunnistettava käynnissä oleva muutos ja ne tavat, joilla he voivat toimia siirtymässä eri alojen toimijoiden tukena. Empiiristä tutkimusta tarvitaan muun muassa ammattikuvien muutoksesta siirtymässä. Mitä uutta osaamista eri aloilla tarvitaan? Miten työkäytännöt muuttuvat, kun siirrytään resurssitehokkuuteen ja kiertotalouteen? Miten työn ympäristövaikutuksia voidaan vähentää muokkaamalla työn tekemisen tapoja? Miten varmistetaan hiipuvien alojen työntekijöiden osaamisen päivitys ja työllisyys? Millaisia ovat kokonaan uudet vihreät ammatit 
esimerkiksi jätehuollossa, vesistöjen ennallistamisessa tai uusiokäytössä? Millaista on oikeudenmukainen ei-inhimillisten toimijoiden tekemä työ? Miten rakennetaan oikeudenmukaista siirtymää työpolitiikassa ja yksittäisillä työpaikoilla? Lisäksi on syytä pysähtyä säännöllisesti myös vahvan kestävyysajattelun esille nostamien kysymysten äärelle: Olemmeko uralla, joka mahdollistaa työpaikkojen määrän ja työllisyyden kasvun irtikytkennän kasvihuonekaasujen päästöjen kasvusta? Rauhanomaisille siirtymille työelämän ja toimeentulon kysymykset ovat olennaisia. Näiden teemojen tutkimuksessa työelämän tutkijoilla on pitkä historia.

\section{Kirjoittajat}

\section{Tiina Taipale}

VTM, väitöskirjatutkija, Aalto-yliopisto

sähköposti: tiina.taipale@aalto.fi

twitter: @tiina_taipale

\section{Eeva Houtbeckers}

KTT, tutkijatohtori, Aalto-yliopisto, Koneen säätiö, Maj ja Tor Nesslingin säätiö sähköposti: eeva.houtbeckers@aalto.fi twitter: @eevahoutbeckers

\section{Kirjallisuus}

Alasoini, T. (2003) Kestävät työjärjestelmät jälkibyrokraattisen työn kehittämishaasteena. Aikuiskasvatus 23 (3), 242-243.

Barca, S. (2015) Greening the job: Trade unions, climate change and the political ecology of labour. Teoksessa R. L. Bryant (toim.) The international handbook of political ecology. Cheltenham: Edward Elgar, 387-400.

Bottazzi, P. (2019) Work and social-ecological transitions: A critical review of five contrasting approaches. Sustainability 11 (14), 3852. https://doi.org/10.3390/ su11143852

D'Alisa, G., Demaria, F. \& Kallis, G. (toim.) (2014) Degrowth: A vocabulary for a new era. New York: Routledge. 
Davidson, K. (2014) A typology to categorize the ideologies of actors in the sustainable development debate. Sustainable Development 22 (1), 1-14. https://doi.org/10.1002/sd.520

Deloitte \& EK (2020) Ilmastonmuutoksen vaikutukset suomalaiseen elinkeinoelämään - skenaariotyön taustaraportti. Deloitten selvitys Elinkeinoelämän keskusliitolle. https://ek.fi/wp-content/uploads/Ilmastonmuutoksenvaikutukset-suomalaiseen-elinkeinoelamaan_Deloitte_EK_raportti_ tammikuu-2020_FINAL.pdf (luettu 4.4.2020)

Di Ruggiero, E., Cohen, J. E., Cole, D. C. \& Forman, L. (2015) Competing conceptualizations of decent work at the intersection of health, social and economic discourses. Social Science \& Medicine 133, 120-127. https://doi.org/10.1016/j.socscimed.2015.03.026

Docherty, P., Mari, K. \& Shani, A. B. R. (2008) (toim.) Creating sustainable work systems: Developing social sustainability. New York: Routledge.

Ewing, J. A. (2017) Hollow ecology: Ecological modernization theory and the death of nature. Journal of World-Systems Research 23 (1), 126-155. https://doi.org/10.5195/jwsr.2017.611

Felli, R. (2014) An alternative socio-ecological strategy? International trade unions' engagement with climate change. Review of International Political Economy 21 (2), 372-398. https://doi.org/10.1080/09692290.2012.761642

Furchtgott-Roth, D. (2012) The elusive and expensive green job. Energy Economics 34 (Supplement 1), S43-S52. https://doi.org/10.1016/j. eneco.2012.08.034

Geels, F. W., McMeekin, A., Mylan, J. \& Southerton, D. (2015) A critical appraisal of sustainable consumption and production research: The reformist, revolutionary and reconfiguration positions. Global Environmental Change 34, 1-12. https://doi.org/10.1016/j.gloenvcha.2015.04.013

Gibson-Graham, J. K., Healy, S., Cameron, J. \& Talvikallio, E. (2019) Elävä talous - Yhteisen tulevaisuuden toimintaopas. Tampere: Vastapaino.

Hajer, M. A. (1995) The politics of environmental discourse: Ecological modernization and the policy process. New York: Oxford University Press.

Hirvilammi, T. \& Joutsenvirta, M. (2020) Diverse work practices and the role of welfare institutions. Teoksessa T. Eskelinen, T. Hirvilammi \& J. Venäläinen (toim.) Enacting community economies within a welfare state. Mayfly Books, 47-70. 
Hirvilammi, T., Mathies, A.-L., Närhi, K. \& Stamm, I. (2016) Kestävää siirtymää edistäviä työn ja toimeentulon muotoja - Analyysi kirjallisuudesta. Janus 24 (4), 301-319.

Honkasalo, A. (2012) Vihreä talous ja vihreät työt: Ekoinnovaatiot ja työperäiset riskitekijät. Helsinki: Ympäristöministeriö.

Houtbeckers, E. \& Taipale, T. (2017) Conceptualizing worker agency for the challenges of the Anthropocene: Examples from recycling work in the Global North. Teoksessa P. Heikkurinen (toim.) Sustainability and peaceful coexistence for the Anthropocene. Abingdon: Routledge, 140-161.

ILO (2008) Green jobs: Towards decent work in a sustainable, low-carbon world. Geneve: International Labour Office.

ILO (2011) Skills for green jobs: A global view. Synthesis report based on 21 country studies. Geneve: International Labour Office.

ILO (2012) Working towards sustainable development: Opportunities for decent work and social inclusion in a green economy. Geneve: International Labour Office.

ILO (2013) Sustainable development, decent work and green jobs. Report V. International Labour Conference, 102nd Session, 2013. Geneve: International Labour Office.

ILO (2015) Guidelines for a just transition towards environmentally sustainable economies and societies for all. Geneve: International Labour Office.

ILO (2016) Green jobs progress report 2014-2015. Geneve: International Labour Office.

ILO (2018a) Greening with jobs. Geneve: International Labour Office.

ILO (2018b) The employment impact of climate change adaptation. Geneve: International Labour Office.

ILO (2018c) Just transition towards environmentally sustainable economies and societies for all. Geneve: International Labour Office.

ILO (2018d) The future of work in a changing natural environment: Climate change, degradation and sustainability. Geneve: International Labour Office. ILO (2019) Skills for a greener future: A global view. Based on 32 country studies. Geneve: International Labour Office. 
Johansson, N. \& Henriksson, M. (2020) Circular economy running in circles? A discourse analysis of shifts in ideas of circularity in Swedish environmental policy. Sustainable Production and Consumption, 23, 148-156. https://doi.org/10.1016/j.spc.2020.05.005

Joutsenvirta, M., Hirvilammi, T., Ulvila, M. \& Wilén, K. (2016) Talous kasvun jälkeen. Helsinki: Gaudeamus.

Järvensivu, P. (2016) Rajattomasti rahaa niukkuudessa. Helsinki: Like.

Järvensivu, T., Järvensivu, P., Schmidt, T. \& Palmu, P. (2012) Työ ekologisesti ja sosiaalisesti kestävässä tulevaisuudessa. Teoksessa T. Helne \& T. Silvasti (toim.) Yhteyksien kirja: Etappeja ekososiaalisen hyvinvoinnin polulla. Helsinki: Kelan tutkimusosasto, 104-115.

Kasvio, A. (2009) Kestävä kehitys ja työelämä. Työpoliittinen aikakauskirja 2/2009, 6-15.

Kasvio, A. (2012) Kestävä työ: Ideasta käytännön ohjenuoraksi. Työpoliittinen aikakauskirja 1/2012, 33-44.

Kasvio, A. (2014) Kestävä työ ja hyvä elämä. Helsinki: Gaudeamus.

Kasvio, A. \& Räikkönen, T. (2010) Kohti kestävää työelämää. Helsinki: Työterveyslaitos.

Kasvio, A., Räikkönen, T. \& Huttunen, A. (2013) Kestävän työn kehittäminen Suomessa uudenlaisten resurssi- ja ympäristöongelmien aikakaudella. Helsinki: Työterveyslaitos.

Kellomäki, S., Peltola, H., Nuutinen, T., Korhonen, K. T. \& Strandman, H. (2008) Sensitivity of managed boreal forests in Finland to climate change, with implications for adaptive management. Philosophical Transactions of the Royal Society B: Biological Sciences 363, 2339-2349. https://doi.org/10.1098/ rstb.2007.2204

Kira, M. \& van Eijnatten, F. M. (2010) Socially sustainable work organizations and systems thinking. Systems Research and Behavioral Science 27 (6), 713-721. https://doi.org/10.1002/sres.1043

Lahikainen, L. \& Toivanen, T. (2019) Working the biosphere: Towards an environmental philosophy of work. Environmental Philosophy 16 (2), 359-378. https://doi.org/10.5840/envirophil2018111480 
Laine, A., Vanhanen, J., Halonen, M., Sjöblom, H. \& Oy, G. C. (2018) Ilmastonmuutoksen aiheuttamat riskit ja kustannukset Suomelle: Valikoituja esimerkkejä. Helsinki: Gaia Consulting.

Massa, I. (2009) Vihreä sopimus uutena yhteiskuntapolitiikan strategiana. Janus 17 (3), 231-247.

Michaels, R. \& Murphy, R. P. (2009) Green jobs: Fact or fiction? Institute for Energy Research.

Miller, E. (2019) Reimagining livelihoods: Life beyond economy, society, and environment. Minneapolis: University of Minnesota Press.

Nugent, J. P. (2011) Changing the climate: Ecoliberalism, green new dealism, and the struggle over green jobs in Canada. Labor Studies Journal 36 (1), 58-82. https://doi.org/10.1177/0160449X10392528

Olsen, L. \& Kemter, D. (2012) The International Labour Organization and the environment: The way to a socially just transition for workers. Teoksessa N. Räthzel \& D. Uzzell (toim.) Trade unions in the green economy: Working for the environment. ProQuest Ebook Central: Taylor \& Francis Group, 1-17. https://doi.org/10.4324/9780203109670

Peltonen-Sainio, P., Pirinen, P., Mäkelä, H. M., Ojanen, H. \& Venäläinen, A. (2016a) Spatial and temporal variation in weather events critical for boreal agriculture: II Precipitation. Agricultural and Food Science 25 (1), 57-70. https://doi.org/10.23986/afsci.51466

Peltonen-Sainio, P., Pirinen, P., Laapas, M., Mäkelä, H. M., Ojanen, H. \& Venäläinen, A. (2016b) Spatial and temporal variation in weather events critical for boreal agriculture: III Frost and winter time fluctuation. Agricultural and Food Science 25 (1), 71-80. https://doi.org/10.23986/afsci.51467

Pollin, R. (2009) Response to "Seven myths about green jobs" and "Green jobs myths". Political Economy Research Institute, Working Paper no 198.

Rasmus, S., Turunen, M., Luomaranta, A., Kivinen, S., Jylhä, K. \& Räihä, J. (2020) Climate change and reindeer management in Finland: Co-analysis of practitioner knowledge and meteorological data for better adaptation. Science of the Total Environment 710: article 136229. https://doi.org/10.1016/j. scitotenv.2019.136229 
Ruuhela, R., Hyvärinen, O. \& Jylhä, K. (2018) Regional assessment of temperaturerelated mortality in Finland. International Journal of Environmental Research and Public Health 15 (3), 406. https://doi.org/10.3390/ijerph15030406

Räikkönen, T. (2011) The greening of work: How green is green enough? Nordic Journal of Working Life Studies 1(1), 117-133. https://doi.org/10.19154/njwls. v1i1.2338

Räikkönen, T. (2013) Askelmerkkejä ekologisesti kestävään työn tulevaisuuteen. Työelämän tutkimus 11 (2), 99-112.

Räikkönen, T. (2016) Työtä luonnon ehdoilla? Resilienssiajattelu ja kestävä työ. Acta Universitatis Tamperensis 2162. Tampere: Tampere University Press.

Standing, G. (2009) Work after globalization: Building occupational citizenship. Cheltenham: Edward Elgar. 


\section{Tiina Taipale \& Eeva Houtbeckers}

Sustainability thinking in the ILO's green jobs reports and working life studies in sustainability transformation

In this article, we explore the perception of working life and environmental issues in the International Labor Organization's (ILO) green jobs reports. These reports include useful outlines for understanding environmental issues in working life. We list the publicly available ILO green jobs reports and describe what themes they include. We focus on two essential themes that emerge from the reports: (1) climate change and (2) the impacts of sustainability transformation on work and employment. We use the distinction of weak and strong sustainability from previous literature to analyse the reports. We claim that familiarisation with the reports' themes enables working life researchers and developers to understand and advance a just transition. We conclude that in addition to supranational relations, working life studies should consider fairness and solidarity between generations and species. 